\title{
Potential of Biocontrol Efficacy of Entomopathogenic Nematodes on White Grubs, Anomalacommunis (Coleoptera: Scarabaeidae) in Potato
}

\author{
Sharmila R*, S. Subramanian, K. Poornima, K. Anitha \\ Department of Nematology \\ Tamil Nadu Agricultural University \\ Coimbatore, Tamil Nadu, India
}

*Corresponding Author: Sharmila R, Department of Nematology, Tamil Nadu Agricultural University

Coimbatore, Tamil Nadu, India

\begin{abstract}
Entomopathogenic nematodes (EPNs) are beneficial nematodes lethal to insect pests and are being successfully used as a bio pesticide against various insect pests. White grubs are the most wide spread and destructive pest in India. In S. glaseri was more effective on communis in potato under lab and pot culture conditions. The highest larval mortality of 83.33 per cent and 19.04 per cent tuber damage was observed with $S$. glaseri@5 × 109 IJ/ha. At the same dosage, H. indica caused 71.66 per cent larval mortality and 38.09 per cent tuber damage. The efficacy of the entomopathogenic nematodes, viz., Heterorhabditisindica and Steirnernemaglaseri were studied against coleopteran insect pests of Anomalacommunis in potato under field conditions. The highest grub mortalitywas 58.32 per cent with S. glaseri @ $5 \times 109$ IJ/ha. Tuber damage was 24.99 per cent and increase in yield was 15.78 t/ha with S. glaseri @ $5 \times 109$ IJ/ha. The treatments showed to work better at the lowest temperature; however the nematode S. glaseri has its best efficacy at the lowest temperature in the field experiment.S. glaseri effectively controlled Anomalacommunis in potato.
\end{abstract}

Keywords: Entomopathogenic nematodes, H.indica, S.glaseri, A.communis, grub morality, tuber damage

\section{INTRODUCTION}

Entomopathogenic nematodes belong to the families Steinernematidae and Heterorhabditidae the most effectively used as biological control agent (Kaya and Gaugler, 1993). Entomopathogenic nematodes (EPNs) are insects killing nematodes it causing insect mortality at 48 to $72 \mathrm{~h}$. This parasitizing ability of EPN have stimulated as effective for the management of insects pest as alternative to chemical in integrated pest management (IPM) programme. EPN have many attributes, which make them a good and promising bio control (Ahmad etal., 2005).

Potato (Solanumtuberosum) is important food crop in the world. India ranks third in potato area (1.90 million ha) and potato in production is estimated to be 530.27 lakh/tonnes (45 million tonnes) with an average yield of 22.9 t/ha (Ministry of Agriculture and farmers welfare, GOI, New Delhi, 2019). White grubs are the most wide spread and destructive pest in India. White grubs form a major group of insect pests, damaging potato, and have a greater emphasis to white grubs in potato (Chandeletal., 2015). White grubs are similar in shape and colour and have fleshy curved bodies with brown heads and well-developed legs which are hardly used for locomotion (Mehta etal. 2010). White grubs feed on root and underground stem (Veeresh and Rajagopal, 1983). The young grubs feed on mother tubers, after new tuber formation, the older second and third in star grubs feed on the tubers (Mehta etal.2010). The second in star white grubs produce smaller holes in tubers and third instar make large, shallow, irregular cavities into potatoes (Chandeletal., 2003).

Anomalacommunis progressively has extended its range in mid and higher hills of India (Ragupathyetal., 1997. Ootyis one of the important potato growing areas in Tamil Nadu, a hilly state in North West India. The combination of imidacloprid with specific nematode Steinernemakushidai 
highly effective against white grub control (Koppenhoferetal., 2000). The damage is mainly caused by the late second and third instar grubs which make large, shallow and market circular holes on tubers (Misra, 1995). The white grubs infest tubers, therefore, have poor tuber value. These grubs damage the tubers without any symptoms on the foliage. Soil is the substrate for these nematodes and hence application in soil results in successful control of various soil pests.

The application of entomopathogenic nematodes as biological control agents in protected environments is well accepted. EPNs carry species specific symbiotic bacteria which, after nematodes infect insect hosts are released into the hemolymph of the host only infective juveniles are able to infect the insect host (Kaya and Gaugler 1993).

The aim of our research was to study the efficacy of entomopathogenic nematodes against the white grub to achieve which species of EPN ( $\mathrm{H}$. indica and S. glaseri) is the most effective as related to temperature and the nematode concentration. The potential efficacy of EPN with regard to white grub for replacing insecticides with the biological control agents is the need of the hour. The most efficient nematode identified from the present field experiment suggested to used in a sustainable strategy of potato production. In this way we will contribute to use eco-friendly production of potato. Research has demonstrated that EPNs at high concentrations, together with favourable abiotic factors (high humidity, optimal temperature) can be effective biological control agents of A. communis in potato.

\section{Materials ANd Methods}

\subsection{Nematodes}

The nematodes viz., H.indica and S.glaseri were obtained from Sugarcane Breeding Institute, Coimbatore and mass cultured inC. cephlonica. The insect larvae were reared on broken cumbu grains sterilized at $100 \mathrm{oC}$ for 30 minutes, according to the procedure of Kaya and Gaugler (1993). The third stage juveniles (IJs) were harvested from water surrounding White's trap within 10 days of emergence from their hosts. A stock suspension of the IJs in distilled water was stored at $20 \mathrm{oC}$ for 2 weeks before use in BOD incubator.

\subsection{Collection of Anomalacommunis}

Third and fourth in star larvae of A. Communis were collected from infested potato fields at Horticultural Research Station, Woodhouse farm, Udhagamandalam.

\subsection{Mass Multiplication of Entomopathogenic nematodes}

In vitromass multiplication of entomopathogenic nematodes species was done in two different media viz., Modified dog biscuit and Modified egg yolk medium (Hussaini, 2002). The ingredients were mixed together in different composition with polyether polyurethane sponge $(1.5 \mathrm{~cm} 3)$. The flasks were filled with foam chips medium mixture (1.5 g of foam chips: $8-9 \mathrm{~g}$ of medium, w/w) and plugged tightly with cotton. The flasks were auto claved for 20 minutes at $121 \mathrm{oC}$ and allowed to cool at room temperature before inoculation with infective juveniles fresh. The infective juvenile fresh are extracted from the infected insect cadavers and used. The nematodes were inoculated aseptically @ 1000 infective juveniles/flask. Care was taken by avoiding the agitation of flasks after the inoculation of nematodes. The sealed flasks were incubated at $28 \mathrm{oC}$ for 30 days. Colonies of the nematodes were observed on the walls of the flasks after 20 days post inoculation. The harvesting of the nematodes was done after 30 days. The nematode yield from each medium harvested were expressed in terms of number of infective juveniles/flask (Sunanda and Siddiqui 2013). The infective juveniles extracted from medium were used for pot culture and filed experiments.

\subsection{Virulence of Entomopathogenic Nematode}

Heterorhabditis indica and S.glaseri were selected for testing virulence against A.communis. Dose - mortality relationship and time mortality tests were conducted in $9 \mathrm{~cm}$ diameter Petri dishes lined at the bottom with a man No. 1 filter paper and moistened with $1 \mathrm{ml}$ sterile distilled water. Infective juveniles were evenly applied over the filter paper. The dosages used were $0,5,10$, 
20, 40, 80and 100 infective juveniles per larva, with 10 larvae per insect per replicate and four replicates for each level.

\subsection{Glass House Conditions}

Two pot culture experiments were conducted for testing the bioefficacy of entomopathogenic nematodes against 4th instar larvae of A. communis on potato under glass house conditions at Horticultural Research Station, Udhagamandalam. Potato tubers (var: KufriJyoti) were surface sterilized and washed in water. They were sown in earthen pots of $5 \mathrm{~kg}$ capacity and two tubers per pot were sown. After germination and establishment of the seedling to inoculate A. communis larvae collected in the potato field were inoculated and starved for one week to increase host adaptation suitability of larvae. The nematode treatments were given as $H$. indica @ 1.25, 2.5 and 5×109 IJ/ha and S. glaseri@1.25,2.5and5×109IJ/ha. The treatments were replicated thrice in a Completely Randomized Design (CRD). The nematodes were inoculated in soil for each treatment. Insect mortality counts were taken every $24 \mathrm{~h}$ up to $72 \mathrm{~h}$ after application. The number of dead larvae were counted and confirmed for the presence of nematodes inside the cadavers. Damaged tubers due to the larvae were also recorded in all the treatments.

\subsection{Field Conditions}

Field experiments were conducted for testing the efficacy of $H$. indica and $S$. glaseri against 3rd and 4th in star larvae of A. communis. The experiment was conducted in potato field naturally infested with white grubs. No entomopathogenic nematode population were recorded from the experimental field. A Randomized Blocks Design field experiment with three replications was conducted in Horticultural Research Station, Woodhouse farm at Udhagamandalam. The plants were raised in $12 \mathrm{~m} 2$ plot size. The potato (Var: KufriJyothi) showing the symptoms of damage infested by the pest by third and fourth in star larvae were selected at random in each plot, labelled and the grub population recorded. The nematode treatments were given as $H$. indica @ 1.25, 2.5 and $5 \times 109 \mathrm{IJ} / \mathrm{ha}$ and S. glaseri@ 1.25, 2.5 and 5×109 IJ/ha. The nematodes were inoculated in soil for each treatment doses / $\mathrm{m} 2$ were applied separately near the base of potato plants. Control plots were drenched with distilled water. Grub mortality counts were taken at 3 days interval up to 7 days after application.

The observation was taken at grubs and other life stages were collected from random locations to determine if they were alive or dead, and were dissected to determine the presence of entomopathogenic nematodes. Data were collected on grub population/ plot, plant damage/plot and damaged tuber/ plot at harvest. The number of dead grubs were counted and confirmed for the presence of nematodes inside the cadavers. Damaged tubers due to the larvae were also recorded in all the treatments.

\subsection{Statistical Analysis}

The observations recorded were statistically analysed and significance of results was tested for the experiments. Means of all experiments were used to compare the efficacy of treatments. Per cent insect mortality data were analysed by multifactor ANOVA followed by Duncan's multiple range test $(\mathrm{P}>0.05)$ for separation of means. The data from pathogenicity tests were subjected to Probit analysis (Finney, 1971) for median lethal concentration (LC50) and median lethal time (LT50).

\section{RESULTS AND DISCUSSION}

Virulence of Heterorhabditis indica was found to be virulent against A. communis with LC50 values $29.77 \mathrm{IJ} /$ larva and LT5038.66 h/ larva respectively. The LC50 value of the above insect pest was not significantly different from each other as the fiducial limits were overlapping. Steinernemaglaseri was found to be highly virulent against larvae of A. communis with lowest LC50 values of $21.48 \mathrm{IJ} / \mathrm{larva}$ and minimum time was taken by A. communis (36.93h/larva) (Table1).

Table1. Virulence of EPN against Anomala communis

\begin{tabular}{|c|c|c|c|c|c|c|c|}
\hline \multirow[b]{2}{*}{$\begin{array}{l}\text { Nematode } \\
\text { species }\end{array}$} & \multirow[b]{2}{*}{ Insect } & \multirow[b]{2}{*}{$\mathrm{Chi}^{2}$} & \multirow[b]{2}{*}{ b } & \multirow[b]{2}{*}{$\pm \mathrm{SE}$} & \multirow[b]{2}{*}{$\begin{array}{c}\text { Lethal dose and } \\
\text { Time }\end{array}$} & \multicolumn{2}{|c|}{ Fiducial limits } \\
\hline & & & & & & Lower & Upper \\
\hline & & 1.48 & 2.21 & 0.23 & $29.77 \mathrm{IJ} /$ larva & 22.39 & 39.58 \\
\hline
\end{tabular}


Potential of Biocontrol Efficacy of Entomopathogenic Nematodes on White Grubs, Anomalacommunis (Coleoptera: Scarabaeidae) in Potato

\begin{tabular}{|l|l|l|l|l|c|c|c|}
\hline H. indica & A. communis & 2.13 & 4.29 & 0.67 & $38.66 \mathrm{~h}$ & 33.66 & 43.31 \\
\hline \multirow{2}{*}{ S. glaseri } & \multirow{2}{*}{ A. communis } & 1.18 & 1.91 & 0.20 & $21.48 \mathrm{JJ} / \mathrm{larva}$ & 15.62 & 29.54 \\
\cline { 3 - 8 } & 2.27 & 4.31 & 0.42 & $36.93 \mathrm{~h}$ & 32.61 & 41.83 \\
\hline
\end{tabular}

Under pot culture condition, all the doses of nematodes tested viz., $1.25 \times 109$, $2.5 \times 109$ and $5 \times 109 \mathrm{IJ} /$ ha were found to be effective against A. communis on potato. The insect mortality increased with increased dosage level and exposure time. The highest larval mortality of 83.33 per cent was observed after $96 \mathrm{~h}$ with $S$. glaseri @ $5 \times 109 \mathrm{IJ} /$ ha followed by $S$. glaseri@ @ $2.5 \times 109 \mathrm{IJ} / \mathrm{ha}$ which recorded 81.66 per cent larval mortality of A. communis. The least mortality $(40.00 \%)$ was observed with $H$. indica $1.25 \times 109 \mathrm{IJ} / \mathrm{ha}$ after $96 \mathrm{~h}$ of exposure time. Similar observation was recorded at 48 and $72 \mathrm{~h}$ of exposure time, the highest larval mortality of 23.33 and 55.00 per cent were caused by S. glaseri @ $5 \times 109 \mathrm{IJ} /$ ha followed by H. indica at $1.25 \times 109 \mathrm{IJ} / \mathrm{ha}$ which recorded 10.00 and 15.00 per cent respectively. Number of damaged potato tubers by insects was found to decrease with increased dosage of nematodes. S. glaseri was found effective than $H$. indica. The least tuber damage of 19.04 per cent was observed with S. glaseri @ $5 \times$ $109 \mathrm{IJ} /$ ha. It was followed by $S$. glaseri $2.5 \times 109 \mathrm{IJ} / \mathrm{ha}, H$. indica @ $5 \times 109 \mathrm{IJ} / \mathrm{ha}$ and $H$. indica @ $2.5 \times 109 \mathrm{IJ} / \mathrm{ha}$ with per cent tuber damage was found to be $28.57,38.09$ and 47.61 respectively, which were on par with each other. The highest tuber damage of 76.18 per cent was found in untreated control plants. In the present study, $H$. indica and $S$. glaseri caused significant reduction in white grub population 30 days after application. However, S. glaseri reduced the grub population more effectively compared to $H$. indica. The white grub population was reduced by 51.28 per cent by S. glaseri @ $5 \times 109 \mathrm{IJ} /$ ha followed by $H$. indica. Heterorhabditis indica caused 48.14 per cent reduction at $2.5 \times 109 \mathrm{IJ} / \mathrm{ha}$.

The results of the field experiment showed that all the doses of nematodes tested viz., $1.25 \times 109,2.5 \times 109$ and $5 \times 109 \mathrm{IJ} / \mathrm{ha}$ were found to be effective against $A$. communis on potato. Observations were made on the mortality of white grub, per cent tuber damage and percentage of healthy tubers and yield. The data revealed that all the treatments had significant effects to control the white grub. $S$. glaseri recorded the highest grub mortality. Nomalacommunis grub mortality was highest (58.32\%) after 7 days for S. glaseri @ $5 \times 109$ IJ/ha. S. glaseri and H. indica @ $2.5 \times 109$ IJ/ha were on par with each other with larval mortality of 45.83 per cent for both the nematodes. A mortality of 20.20 per cent in white grubs was observed with H. indica@ $1.25 \times 109$ after 7 days exposure period. The similar observation was noticed at 4 days interval, with highest larval mortality of 54.16 per cent was caused by $S$. glaseri @ $5 \times 109 \mathrm{IJ} /$ ha and lowest larval mortality due to $H$. indica@1.25 × 109 which recorded at 12.49 per cent. The per cent tuber damage observed with $S$. glaseri@1.25 and $5 \times 109 \mathrm{IJ} /$ ha was 21.42 and 53.56 per cent respectively compared to control $(60.71 \%)$.

The reduction in grub population was 60 per cent due to $S$. glaseri and more than 40 per cent due to $H$. indica. The mean per cent healthy tuber was recorded in $S$. glaseri viz., 78.58 per cent and $H$. indica 75.01 per cent @ $5 \times 109 \mathrm{IJ} /$ ha respectively. The highest increase in grub mortality and increase in yield over control due to grub mortality was recorded as 15.78t/ha and $9.36 \mathrm{t} / \mathrm{ha}$ respectively in control when $S$. glaseri was applied @ $5 \times 109 \mathrm{IJ} /$ ha. Lowest decrease in grub mortality resulted in increase in yield over control (14.89 and 9.36t/ha) with $H$. indica at $5 \times 109$ IJ/ha. Treatment with $S$. glaseri at higher dosage of $5 \times 109 \mathrm{IJ} /$ ha was highly significant over all the treatments, as in this treatment no grub and tuber damage were observed after application (Fig 1).

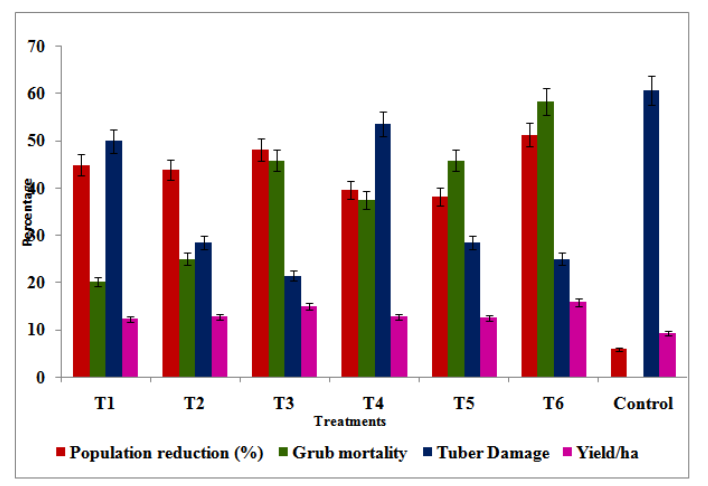

Fig1. Bioefficacy of entomopathogenic nematodes against A. communis on potato 
T1- H. indica@ 1.25×109 IJs/ha, T2- H. indica @ 2.5×109 IJs/ha, T3- H. indica @ 5×109 IJs/ha, T4S. glaseri @ 1.25×109 IJs/ha, T5- S. glaseri @ 2.5×109 IJs/ha, T6- S. glaseri @ 5×109 IJs/ha, T7Control

(Pooled mean of two experiments)

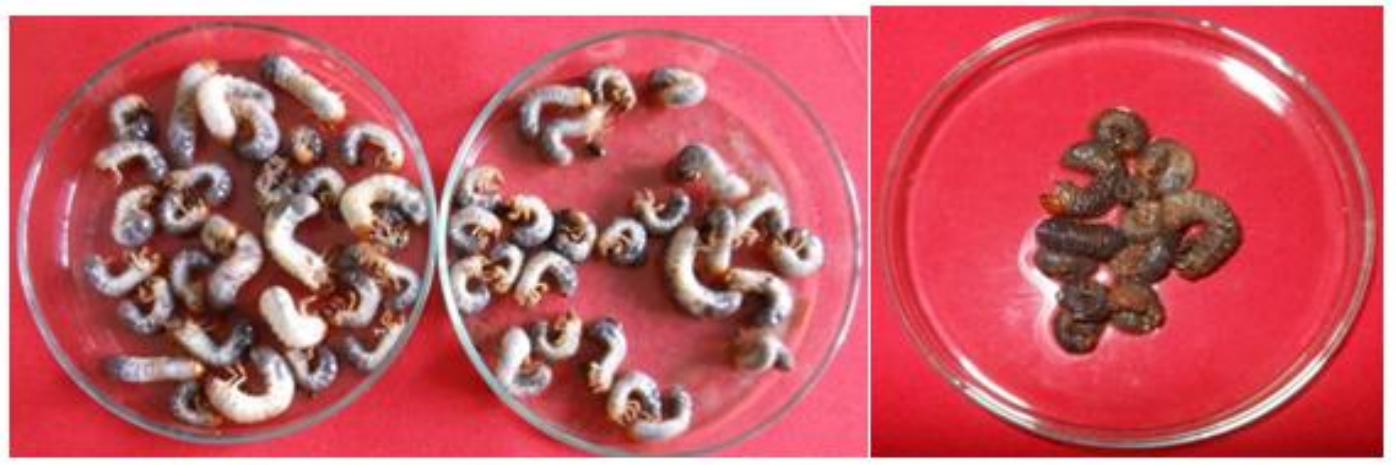

White grubs from in infected potato field before treatments

After treatments

Figure1. Bioefficacy of entomopathogenic nematodes against A. Communis under field conditions

Table2. Bioefficacy of entomopathogenic nematodes against A. communis on potato under field conditions (Pooled mean of two experiments)

\begin{tabular}{|c|c|c|c|c|c|c|c|c|}
\hline \multirow[t]{2}{*}{ Treatments } & \multirow[t]{2}{*}{$\begin{array}{c}\text { Pre } \\
\text { application } \\
\text { population/m² }\end{array}$} & \multirow[t]{2}{*}{$\begin{array}{c}\text { Post } \\
\text { application } \\
\text { population } \\
\text { (35 days) }\end{array}$} & \multirow[t]{2}{*}{$\begin{array}{l}\text { Population } \\
\text { reduction } \\
(\%)\end{array}$} & \multicolumn{2}{|c|}{$\begin{array}{c}\text { *Per cent grub } \\
\text { mortality } 3^{\text {rd }} \\
\text { instar (days } \\
\text { after treatment) }\end{array}$} & \multirow[t]{2}{*}{$\begin{array}{c}\text { *Tuber } \\
\text { damage } \\
(\%)\end{array}$} & \multirow[t]{2}{*}{$\begin{array}{c}\text { Healthy } \\
\text { tubers } \\
(\%)\end{array}$} & \multirow[t]{2}{*}{$\begin{array}{l}\text { Yield } \\
\text { kg/ha }\end{array}$} \\
\hline & & & & 4 days & 7 days & & & \\
\hline $\begin{array}{c}\mathrm{T}_{1}-H . \\
\text { indica } @ \\
1.25 \times 10^{9} \\
\text { IJs/ha }\end{array}$ & 49 & 27 & 44.89 & $\begin{array}{c}12.49^{\mathrm{e}} \\
(18.13)\end{array}$ & $\begin{array}{c}20.20^{\mathrm{d}} \\
(26.88)\end{array}$ & $\begin{array}{c}49.99^{b} \\
(44.99)\end{array}$ & 50.01 & 12.31 \\
\hline $\begin{array}{c}\mathrm{T}_{2^{-}} H . \\
\text { indica } @ \\
2.5 \times 10^{9} \\
\text { IJs/ha }\end{array}$ & 41 & 23 & 43.90 & $\begin{array}{c}20.82^{\mathrm{e}} \\
(26.88)\end{array}$ & $\begin{array}{l}24.99^{\mathrm{cd}} \\
(29.67)\end{array}$ & $\begin{array}{c}28.57^{\mathrm{c}} \\
(32.31)\end{array}$ & 71.43 & 12.78 \\
\hline $\begin{array}{l}\mathrm{T}_{3}-H . \\
\text { indica } @ \\
5 \times 10^{9} \\
\text { IJs/ha }\end{array}$ & 27 & 14 & 48.14 & $\begin{array}{l}45.83^{a b} \\
(42.56)\end{array}$ & $\begin{array}{l}45.83^{\mathrm{ab}} \\
(42.56)\end{array}$ & $\begin{array}{c}24.99^{c} \\
(29.78)\end{array}$ & 75.01 & 14.89 \\
\hline $\begin{array}{c}\mathrm{T}_{4^{-}} \mathrm{S} . \\
\text { glaseri } @ \\
1.25 \times 10^{9} \\
\mathrm{IJ} / \mathrm{ha} \\
\end{array}$ & 48 & 29 & 39.6 & $\begin{array}{c}24.99^{c} \\
(29.67)\end{array}$ & $\begin{array}{l}37.49^{b c} \\
(37.69)\end{array}$ & $\begin{array}{l}53.56^{\mathrm{ab}} \\
(47.05)\end{array}$ & 46.44 & 12.78 \\
\hline $\begin{array}{c}\mathrm{T}_{5}-S . \\
\text { glaseri@ } \\
2.5 \times 10^{9} \\
\text { IJs/ha }\end{array}$ & 47 & 29 & 38.29 & $\begin{array}{l}37.49^{b c} \\
(37.69)\end{array}$ & $\begin{array}{l}45.83^{a b} \\
(42.56)\end{array}$ & $\begin{array}{c}28.57^{\mathrm{c}} \\
(32.31)\end{array}$ & 71.43 & 12.56 \\
\hline $\begin{array}{c}\mathrm{T}_{6}-S . \\
\text { glaseri @ } \\
5 \times 10^{9} \\
\text { IJs/ha }\end{array}$ & 39 & 19 & 51.28 & $\begin{array}{c}54.16^{\mathrm{a}} \\
(47.43)\end{array}$ & $\begin{array}{l}58.32^{a} \\
(49.86)\end{array}$ & $\begin{array}{c}21.42^{c} \\
(27.25)\end{array}$ & 78.58 & 15.78 \\
\hline $\mathrm{T}_{7}-$ Control & 51 & 48 & 5.88 & $\begin{array}{c}0 \\
(0.28) \\
\end{array}$ & $\begin{array}{c}0 \\
(0.28) \\
\end{array}$ & $\begin{array}{c}60.71^{\mathrm{a}} \\
(51.24) \\
\end{array}$ & 39.29 & 9.36 \\
\hline $\begin{array}{c}C D \\
(p=0.05)\end{array}$ & & & & 9.32 & 9.23 & 6.23 & & \\
\hline
\end{tabular}

Figures in parentheses are arc sine transformed values*

Column figures followed by different letters are significantly different from each other 
The present investigation indicated that $S$. glaseri were more virulent to A. communis. Virulence of entomopathogenic nematodes was also affected by different larval stages of white grubs as reported by Ma etal. (2013). The highest larval morality was observed after 96 h with S. glaseri @ $5 \times 109$ IJ/ha followed by S. glaseri @ $2.5 \times 109$ IJ/ha. The least mortality was observed with H. indica @ $1.25 \times 109 \mathrm{IJ} / \mathrm{ha}$ after $96 \mathrm{~h}$ of exposure time. Similar observation was made in white grubs, which showed a did not clear trend for which larval stage was the optimal one for entomopathogenic nematodes and it varied with different entomopathogenic nematodes species and different white grub species(Grewaletal.,2004).Combination of $S$. carpocapsae and $H$. indica had an additive effect over their individual population. $S$. carpocapsae has been reported to perform well against some white grub species (For schler and Gardner 1991). Sharma etal. (2009) reported S. carpocapsae is better than $H$. indica for controlling white grubs. This may be due to the better survival and adaptability of S. carpocapsae in the soil of the hilly area. Guoetal. (2015) reported that S. longicaudum X7 and $\mathrm{H}$. bacteriophora $\mathrm{HO}$ showed good control efficacy against Holotrichiaoblita larvae, but $\mathrm{H}$. bacteriophora $\mathrm{HO}$ was recommended as a promising agent for white grub control in practice. S. glaseri was highly effective against this sedentary pest (Almetal., 1992). In the environmental conditions are favourable for (temperature, moisture, relative humidity and soil type) entomopathogenic nematodes and produce long term effects on pest population (Susurluketal., 2011).

We conducted trail to evaluate management options for potato field experiment.In the present study population of white grub were reduced by 51.28percent when treated with $S$. glaseri followed by $H$. indica showing 39.60 per cent reduction. Banuetal. (2003) reported mortality of insects with the increased level of entomopathogenic nematodes. The zero mortality of nematode was observed up to 5 days after treatment. Similar result of 35 and 21 per cent mortality was recorded against second in star white grub for $\mathrm{H}$. indica and $\mathrm{H}$. bacteriophora respectively (Anonymous, 2000). Highest grub mortality was 58.32 per cent after 7 days for S. glaseri @ $5 \times 109$ IJ/ha. S. glaseri and H. indica @ $2.5 \times 109 \mathrm{IJ} / \mathrm{ha}$ were on par with each other with larval mortality of 45.83 per cent respectively. The result of Anupam Sharma etal. (2009) is similar to the present findings which reveals thatin field conditions all the dosages of $S$. carpocapsae and $H$. indica $(1,3$ and $6 \times 105 \mathrm{IJ} / \mathrm{m} 2)$ were effective in reducing the grub population, plant damage as well as tuber damage. Reduction in grub population was 60-80 per cent due to $H$. indica and more than 83 per cent due to $S$. carpocapsae. These observations are related to Koppenhofer and Fusy (2008) who reported that controlling white grub with $\mathrm{H}$. bacteriophora is safe and highly Integrated Pest Management- compatible alternative for white grub control.

The least mortality of the grubs was observed in present study with $H$. indica@ $1.25 \times 109$ after 4 days of exposure period. The same observation was recorded at 7 days of exposure time. The highest larval mortality of 56.61 per cent was caused by S. glaseri @ $5 \times 109 \mathrm{IJ} /$ ha and lowest larval mortality was caused due to $H$. indica @ $1.25 \times 109$. Previous work of Georgis and Gaugler (1991) and Hussainietal. (2005a) reported the consistent behaviour of entomopathogenic nematodes expecially S. carpocapsae in fields. However the present findings showed that in laboratory, early grub mortality was caused by $S$. glaseri effectively than $H$. indica. Again in the field, $S$. glaseri reduced grubs population more effectively than $H$. indica. This result agrees with Hussainietal. (2005) that Steinernema spp. in turf grass caused 30-40 per cent mortality whereas Heterorhabditis spp. caused 20-25 per cent mortality at 10 days after nematode application. The highest decrease in grub mortality over control and increase in yield over control recorded $15.78 \mathrm{t} / \mathrm{ha}$ and $9.36 \mathrm{t} / \mathrm{ha}$ in S. glaseri @ $5 \times$ $109 \mathrm{IJ} / \mathrm{ha}$ treatment. Lowest decrease in grub mortality and increase in yield over control were observed at 14.89 and 9.36 t/ha in H. indica $5 \times 109 \mathrm{IJ} / \mathrm{ha}$. Koppenhofer and Fusy (2003) reported that in field experiment, $S$. scarabaei showed excellent efficacy with 4-9 times higher control than H. bacteriophora.

The entompathogenic nematodes dispersal and persistence in soil, in turn depend upon many abiotic environmental factors, such as soil moisture, temperature and soil texture. Several studies have demonstrated the influence of temperature on the infectivity of entomopathogenic nematodes (ElSadawy, 2001).The result of the present study suggests that $S$. glaseri is better than $H$. indica for controlling white grubs. This may be due to better survival at low temperature and adaptability of $S$. glaseri in the soil of the hilly area of Ooty. Therefore it is recommended for the bio-intensive management of white grub in potato crop. 


\section{CONCLUSiON}

It is concluded that, biological control can be used as an alternative to chemical pesticides for the control of various insect pests. The highest larval mortality of 83.33 per cent and 19.04 per cent tuber damage was observed with S. glaseri @ $5 \times 109$ IJ/ha under pot culture and field conditions. Infield conditions, $S$. glaseri effectively controlled Anomalacommunis in potato filed. The treatments proved to work better at the lowest temperature; however the nematode $S$. glaseri has its best efficacy at the lowest temperature in the field experiment. However, further studies are required to conclude the formulation that can succeed the best results for management of insect pests.

\section{ACKNOWLEDGEMENT}

The authors acknowledge the University Grants Commission (UGC), New Delhi for the financial support in the form of fellowship.

\section{REFERENCES}

[1] Ahmad R, SS Ali, and Rashid Pervez. 2009. "Field Efficacy of Steinernema Masoodi Based Biopesticide against Helicoverpa Armigera ( Hübner ) Infesting Chickpea.Trends in Biosci 2 (1): $23-24$.

[2] Alm SR, Tamson Yeh, James L Hanula, and Ramon Georgis. 1992. "Biological Control of Japanese , Oriental, and Black Turfgrass Ataenius Beetle (Coleoptera :Scarabaeidae) Larvae with Entomopathogenic Nematodes ( Nematoda : Steinernematidae, Heterorhabditidae ), J Econ Entomol 85 (5): 1660-1665.

[3] Anonymous. 2000. “Annual Report. Sugar Cane Breeding Institute. Coimbatore.

[4] Banu J. Gulsar, Rajendran G., Subramanian S. 2003. "Susceptibility of Red Weevil, Rhynchophorus Ferrugineus Oliv to Entomopathogenic Nematodes." Annals of Plant Prote Sci 11 (1): 104-6.

[5] Chandel RS, Chandla VK and Sharma A. 2003. "Population Dynamics of Potato Whitegrubs in Shimla Hills." J of Indian Potato Associa 30: 151-52.

[6] Chandel RS, Pathania M, Verma KS, Bhattacharyya B, Vashisth and Kumar V. 2015. "The Ecology and Control of Potato Whitegrubs of India Potato Res 58:147-164. https://doi.org/10.1007/s11540-015-9295-3.

[7] Forschleri BT and Gargner WA. 1991. Field Efficacy and Persistence of Entomogenous Nematodes in the Management of White Grubs (Coleoptera: Scarabaeidae) in Turf and Pasture.J of Econ Ento 84 (5): 1454-59.

[8] Koppenhoper AM and Fuzy EM,. 2008. "Early Timing and New Combinations to Increase the Efficacy of Neonicotinoid - Entomopathogenic Nematode ( Rhabditida : Heterorhabditidae ) Combinations against White Grubs ( Coleoptera : Scarabaeidae )

[9] Pest Manag Sci 64:725-735 735. https://doi.org/10.1002/ps.

[10] Georgis, R and Gaugler, R. 1991. "Predictability in Biological Control Using Entomopathogenic Nematodes." Journal of Economic Entomology 84 (3): 713-20.

[11] Grewal, P S, K T Power, S K Grewal, ASuggars, and S Haupricht. 2004. "Enhanced Consistency in Biological Control of White Grubs (Coleoptera :Scarabaeidae) with New Strains of Entomopathogenc Nematodes Biol Contr 30:7382 .https://doi.org/10.1016/j.biocontrol.2003.09.016.

[12] Guo, Wenxiu, Xun Yan, Guoyu Zhao, Jinghua Chen, and Richou Han. 2016. "Efficacy of Entomopathogenic Steinernema." Journal of Pest Science 88: 359-368. https://doi.org/10.1007/s10340-01 4-0626-y.

[13] El-SadawyHA.2001. "Effect of Temperatures and Soil Moisture on the Infectivity of Some Entomopathogenic Nematodes against Larvae of the Rice Moth and the Flesh Fly."International Journal of Nematology 11 (1):5862. https://scholar.google.com/scholar?hl=en\&as_sdt=0,5\&cluster=4146206082198 468233.

[14] Harry K. Kaya and Gaugler R. 1993. "Entomopathogenic Nematodes.” Annual Review of Entomology 38: $181-206$.

[15] Hussaini S.S., Singh S.P., Parthasarathy R., Shakeela V. 2002. "InVitro Production of Entomopathogenic Nematodes in Different Artificial Media." Indian Journal of Nematology 32 (1): 44-46.

[16] Hussaini S.S.*, Nagesh M., Dar Manzoor H., Rajeshwari R. 2005. "Field Evaluation of Entomopathogenic Nematodes against White Grubs (Coleoptera : Scarabaeidae) on Turf Grass in Srinagar." Annals of Plant Protection Sciences 13 (1): 190-93.

[17] S. S. Hussaini, V. Shakeela and MH. Dar. 2005a. "Influence of Temperature on Infectivity of Entomopathogenic Nematodes against Black Cutworm, Agrotis Ipsiloll (Hufnagel) and Greater Wax Moth, Galleria Mellonella (Linnaeus) Larvae.” Journal of Biological Control 19 (1): 51-58. 
[18] Koppenhöfer AM., and Fuzy EM. 2003. "Steinernema Scarabaei for the Control of White Grubs." Biological Control 28 (1): 47-59.

[19] Koppenhöfer AM, Ganguly S and Kaya HK. 2000. "Ecological Characterisation of Steinernema Monticolum , a Cold-Adapted Entomopathogenic Nematode from Korea."

[20] J.Nematology 2 (4): 407-16.

[21] Ma J, S.L. Chen, M. Moens, R.C. Han and P. De Clereq. 2013. "Efficacy of Entomopathogenic Nematodes (Rhabditida: Steinernematidae and Heterorhabditidae) against the Chive Gnat, Bradysia Odoriphaga." Journal of Pest Science 86 (3): 551-61. https://link.springer.com/article/10.1007/s10340013-0497-7.

[22] Mehta PK, Chandel RS and Mathur YS. 2010. "Status of White Grubs in North Western Himalaya." Journal of Insect Science 23 (1): 1-14.

[23] Misra SS. 1995. "Potato Pests and Their Management." shimla.

[24] Regupathy A Palanisamy S Chandramohan N and Gunathilagaraj k. 1997. A Guide on Crop Pests. Coimbatore: Sooriya Desk Top Publishers.

[25] Sharma, Anupam, and Chandla VK. 2009. Use of Steinernema and Heterorhabditis nematodes for control of white grubs , BrahminaCoriacea hope ( Coleoptera : Scarabaeidae ) in potato crop, Potato J 36(3-4) 160165.

[26] Sunanda BS. and Siddiqui AU. 2013. "In Vitro Production of Steinernema Carpocapsae in Different Artificial Media.” Indian Journal of Nematology 43 (1): 40-42.

[27] Susurluk, I Alper, and N Alper Kumral. 2011. "Control of a New Turf Pest, Dorcadion Pseudopreissi ( Coleoptera : Cerambycidae ), with the Entomopathogenic Nematode Heterorhabditis Bacteriophora, J Pest Sci 84:321-326. https://doi.org/10.1007/s10340-011-0358-1.

[28] Veeresh GK. and Rajagopal D. 1983. Applied Soil Biology and Ecology. Edited by Veeresh GK and Rajagopal D.\. Bangalore: Sharada Publishers. https://www.cabdirect.org/cabdirect/abstract/19840517723.

Citation: Sharmila R., et.al," Potential of Biocontrol Efficacy of Entomopathogenic Nematodes on White Grubs, Anomalacommunis (Coleoptera: Scarabaeidae) in Potato International Journal of Research Studies in Zoology, vol. 5, no. 4, p. 8-15, 2019. DOI: http://dx.doi.org/10.20431/2454-941X.050402.

Copyright: () 2019 Authors. This is an open-access article distributed under the terms of the Creative Commons Attribution License, which permits unrestricted use, distribution, and reproduction in any medium, provided the original author and source are credited. 